\title{
HYDROGEOCHEMICAL CHARACTERISTICS OF THE AYGIR GEDIĞI SPRING, BOZKIR/KONYA, SOUTHERN TURKEY
}

DOI: http://dx.doi.org/10.18509/GBP.2019.16

UDC: 553.75:556.36.047(560)

\author{
Güler Göçmez \\ Tuba Köse \\ Kerim Koçak \\ Konya Technical University, Faculty of Engineering and Natural Sciences, \\ Department of Geological Engineering, Turkey
}

\begin{abstract}
The Aygır Gediği spring is located in the southern Turkey, $144 \mathrm{~km}$ to Konya province. In the study area, the units are of belonging to Hadim Napi and Sinatdagi Nap (Ekinlik Formation). At the top, there is Quaternary alluvium. The water source is discharged from the Lower-Middle Triassic Ekinlik Formation, which are highly fractured, cracked and karstic dolomitic limestone and sandstone and shale alternations. The spring is a typical karstic one, which is characterized by a temperature of $13{ }^{\circ} \mathrm{C}$, a flow rate of $2,2 \mathrm{~m} 3 / \mathrm{sec}$, a $\mathrm{pH}$ of 7.74-7.90 and an electrical conductivity of $155-467 \mu \mathrm{mho} / \mathrm{cm}$. Feeding and discharge periods of the source range from January to April, and April to October, respectively. The flow rates are between $2-5 \mathrm{~m} 3 / \mathrm{sec}$ and $0,063-0,095 \mathrm{~m} 3 / \mathrm{sec}$ during the feeding period and discharge period, respectively. The dominant ions in the spring water are calcium, magnesium and bicarbonate, and can be classified as calcium, magnesium, sodium, chlorinated water based on the AIH classification (Association of International Hydrogeology). According to the Schoeller diagram, water in the study area is of the same origin and the order of ions is $\mathrm{rMg}>\mathrm{rCa}>\mathrm{rNa}>\mathrm{K}, \mathrm{rHCO}_{3}>\mathrm{rCl}>\mathrm{rSO}_{4}$.
\end{abstract}

Keywords: Aygır Gediği, spring, karst, flow rate, ion

\section{INTRODUCTION}

The study area is located in the southern Turkey, $164 \mathrm{~km}$ to Konya. The Aygır Gediği spring has been used for drinking and utility water, and picnic area by the local people, as well as domestic tourism for trecking. Though several studies have been performed on general geology and mineralogy of the region $[1,2,3,4,5,6]$. No studies have been performed on hydrogeological characteristics of the region. The region is located in the transition zone between the continental and Mediterranean climates. The average monthly rainfall in 2018 was $42.9 \mathrm{~mm}$, and the average monthly temperature was $12.9^{\circ} \mathrm{C}$.

Units of Hadim Nappe and the Sinatdağ 1 Nap crop out in the study area, all of which is covered unconformably by Quaternary alluvium. The aquifer rock is represented by Carboniferous fractured and cracked limestones. The spring in the region is characterised by existence of multiple outlets. As expected, the discharge from the source gradually increases during the feeding period, and decreases during the discharge period. The discharge makes two of the spring outlets dry out in the summer months. The surrounding area is used as promenade area by the local people. 


\section{GEOLOGY\&HYDROGEOCHEMISTRY}

The Hadim Nappe and the Sinatdağ 1 Nappe are crop out in the region, where the Quaternary alluvium is found at the top (Figure 1). The Late Cretaceous ophiolites and detritics of Dipsizgöl Ophiolitic mélange are the oldest units in the area. The sequence continues with the obduction of Golbogazı formation with dolomitic limestone and sandstone alternations, limestones of Yarıcak formation, and Çekiçdag formation, all of which are belong to the Hadim Napp. The Sinatdag1 Napp overlied all units, contains Hocalar formation, with dolomitic limestone, quartzite and slates [4]. The sequence continues concordantly with Early-Middle Carboniferous Kongul Formation including limestones and shales, and Late Permian Taşkent Formation with limestones, all of which are overlain unconformably by Middle Triassic neritic limestones of Ekinlik Formation, and Late Triassic-Early Jurassic Morbayır Formation with red-colored sandstone and conglomerates. The Cretaceous Sinatdağ 1 Formation overlain concordantly the Morbayır formation, and is overlain unconformably by Topyatak and Sögüt formations. Slope debris and alluviums, the youngest in the area, covers all units unconformably [4].

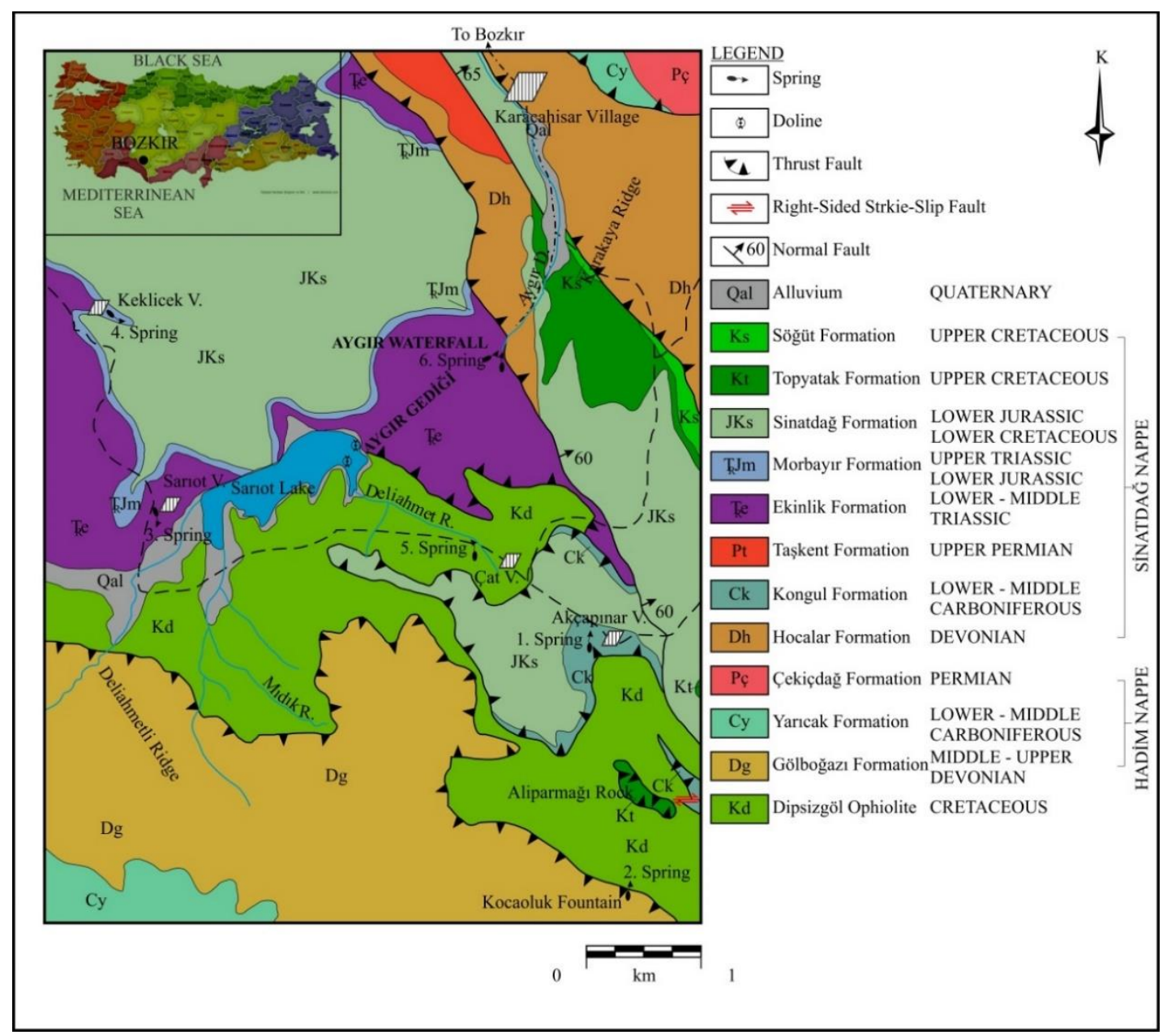

Figure 6. Location map and geological map of the study area [4].

The Aygır Gediği spring, a karstic source, has a temperature of $13{ }^{\circ} \mathrm{C}$, a flow rate of 2,2 $\mathrm{m}^{3} / \mathrm{sec}, \mathrm{pH}$ of 7,74-7,9 and an electrical conductivity of $155-467 \mu \mathrm{mho} / \mathrm{cm}$. The feeding period of the spring ranges from January to April while discharge period is between April and October [7]. 
During the feeding period, the flow rate is between $2-5 \mathrm{~m}^{3} / \mathrm{sec}$ and the discharge period is between $0.063-0.095 \mathrm{~m}^{3} / \mathrm{sec}$. Aygır Gediği spring is fed by precipitation, and hence low precipitation causes flow rate to decrease. In the spring water, the dominant ion is calcium, magnesium and bicarbonate. Calcium and bicarbonate ions are likely to be originated from limestones, magnesium dolomitic limestones while potassium and sulphate ions are from quartzite and shales, respectively [7].

The water source is calcium, magnesium, sodium, chlorinated water according to the AIH classification [8]. According to the Schoeller diagram, water in the study area is of the same origin and the order of ions are $\mathrm{rMg}>\mathrm{rCa}>\mathrm{rNa}>\mathrm{K}, \mathrm{rHCO}_{3}>\mathrm{rCl}>\mathrm{rSO}_{4}$ [9]. According to the Piper diagram, waters are in the 5th zone (carbonate hardness> noncarbonate hardness). Water is classified as $\mathrm{CaCO}_{3}$ and $\mathrm{MgCO}_{3}$ with a carbonate hardness of more than 50\% [10]. According to the Wilcox diagram, it is in the class of good usable waters.

\section{DISCUSSION\&CONCLUSIONS}

Aygır Gediği source has a karst feature, and hosted by highly fractured, cracked and karstic limestones. The limestone was undergone karstification process, which increase and/or intensify the secondary porosity and permeability, hence signifying its aquifer characteristic. The source is fed by rain water, therefore its flow rate decreases due to the decrease in precipitation. The dominant ion in the source water is $\mathrm{Mg}, \mathrm{Ca}$ and $\mathrm{HCO}_{3}$. According to the Piper diagram, the water can be classified as $\mathrm{CaCO}_{3}$ and $\mathrm{MgCO}_{3}$, with a carbonate hardness of more than $50 \%$. In the vicinity of the resources, protection areas should be identified and necessary precautions should be taken for all kind of pollution.

\section{REFERENCES}

[1] Dean, W.T., Özgül, N., 1981. Orta Toroslarda Çaltepe Formasyonu'nun Bağdaş1 (HadimKonya) Yöresindeki Yüzeylemesinde Bulunan Orta Kambriyen Trilobitleri, Maden Tetkik ve Arama Enstitüsü, Ankara.

[2] Koçak, K., 2016. Bozkır (Konya, Orta Toroslar) Yöresinin Jeolojik Özellikleri. 9. Uluslararas1 Sempozyum: Geçmişten Günümüze Bozkır, Konya, 1503-1516.

[3] Özgül, N., 1976. Torosların Bazı Temel Jeoloji Özellikleri, Türkiye Jeoloji Kurumu Bülteni, c. $19,5-78$.

[4] Özgül, N., 1997. Bozkır- Hadim- Taşkent (Orta Torosların Kuzey Kesimi) Dolayında Yer Alan Tektono- Stratigrafik Birliklerin Stratigrafisi, Maden Tetkik ve Arama Dergisi, 119, 113174.

[5] Öztürk, A., Karadağ, M.M., Deli, A., 2008. Bozkır (Konya) İlçesinin Doğu Ve Güneyini Kapsayan Bölgenin Stratigrafisi, Selçuk Üniversitesi Mühendislik Mimarlık Fakültesi Dergisi, 23(4), 11-26.

[6] Turan, A., 1990. Toroslarda Hadim (Konya) ve Güneybatısının Jeolojisi, Stratigrafisi ve Tektonik Gelişimi, Selçuk Üniversitesi Fen Bilimleri Enstitüsü, Doktora Tezi, Konya.

[7] Fetter, C, W., 2000. Applied hydrogeology. CBS Publishers, New Delhi.

[8] Canik, B., 1998, Hidrojeoloji Yeraltı Sularının Aranması, İşletilmesi, Kimyası Ankara Ünv. Fen Fakültesi Matbaası, Ankara.

[9] Schoeller, H. 1962. Les Eaux Souterraines. Mason et.Cie, Paris.

[10] Piper.A.M. 1994 A graphic procudure in the geochemical interpretalion of water analiyses. trans. Amer. Geophys. Union, 25,pp. 914-923. 